\title{
Research on Educational Cost Input Proportional Structure of Colleges and Optimization
}

\author{
Zhao Libing \\ Chengde Medical University \\ Chengde ,Hebei, 067000 China
}

\begin{abstract}
The allocation of educational resources has attracted people's attention for a long time, and there are many relevant researches in theoretical fields. Higher-education reform has made gratifying achievements. But how to improve the internal operation management of schools and optimize cost input structure to improve economic benefit has been ignored. Based on relevant theories and educational expenditure data of universities, the paper applies statistical theory to make empirical analysis on higher-education cost input proportion structure, factors influencing structure and structural output, and proposes the thought of optimizing cost structure of higher education, which provides reference for management of universities.
\end{abstract}

Keywords- institution of higher education, educational cost, optimize, model, regression analysis

\section{I.INT RODUCTION}

In order to realize healthy development, higher education not only needs to increase the investment on higher education, but also needs to optimize the allocation of educational resources and improve efficiency in school management. While the educational resources are deficient and the investment on education is not enough in China, there are the problems that educational resources waste and the output benefit of education investment is not good. And the phenomenon that educational resources waste is common in the field of higher education. The internal management system and operation system of universities is in transitional stage. But the original management system and operation system restricts the reform and development of schools. And how to improve the internal operation management of universities, optimize resource allocation to improve economic benefit is ignored, which not only makes the schools can't adjust educational cost investment structure and allocate resources based on economic rules, but also makes wrong allocation on limited resources of universities.

The paper uses the system engineering method to establish mathematical model to optimize the allocation of educational cost structure, designs resource utilization efficiency evaluation index of higher education, and establishes evaluation model to evaluate cost structure of higher education.

\section{II.ANALYSIS ON FACTORS INFLUENCING PROPORTIONAL STRUCT URE OF HIGHER-EDUCATIONAL COST INPUT}

\section{A. Research design}

The paper uses non-parametric test of independent samples (K-W test) to infer the influence of relevant factors on cost input. The basic method of K-W test is as follows. The samples are sorted in ascending order, and the rank of each observed value is solved. And the mean of the ranks of the samples is solved. If the average order of the samples is the same, the distribution of many independent samples has no evident difference. If the difference is evident, it is impossible that the distribution of independent samples has no evident difference. SPSS automatically calculates k-w statistics, and gets the probability value of $\mathrm{k}-\mathrm{w}$ statistics in critical value table of $\mathrm{K}-\mathrm{W}$ test. If the probability value is less than or equal to significance level $\alpha(\alpha=0.05), \mathrm{H}_{0}$ is rejected, which means that the distribution of independent samples has evident difference. Or the distribution of independent samples has no evident difference.

The paper selects school-running level, the location of schools, administrative departments, variety of schools, school size, teacher resources and material resources as control factors, and selects cost input as variables for nonparameter test.

\section{B. Influence analysis of school-running level}

The school-running level of colleges is divided into three levels, emphasis, general undergraduate and college, which are selected as control variables $(0,1$ and 2$)$. The proportional data of cost is input into the computer as observable variables (316 colleges, 474 undergraduates and 106 emphases). The analysis results are shown in Table 1 and Table 2.

Table 1 Mean rank test of school-running level

\begin{tabular}{|c|c|c|c|c|c|c|c|}
\hline $\begin{array}{c}\text { C } \\
\text { ode }\end{array}$ & $\begin{array}{c}\text { Human } \\
\text { cost }\end{array}$ & $\begin{array}{c}\text { Comm } \\
\text { on cost }\end{array}$ & $\begin{array}{c}\text { Duty } \\
\text { cost }\end{array}$ & $\begin{array}{c}\text { Busine } \\
\text { ss cost }\end{array}$ & $\begin{array}{c}\text { Equip } \\
\text { ment cost }\end{array}$ & $\begin{array}{c}\text { Repair } \\
\text { cost }\end{array}$ & $\begin{array}{c}\text { Other } \\
\text { cost }\end{array}$ \\
\hline 0 & 457.56 & 439.44 & 514.36 & 342.53 & 484.26 & 437.96 & 419.16 \\
\hline 1 & 454.72 & 442.28 & 427.29 & 475.85 & 440.52 & 476.82 & 444.96 \\
\hline 2 & 393.66 & 503.34 & 347.01 & 642.09 & 377.58 & 353.26 & 551.82 \\
\hline
\end{tabular}


Table $2 \mathrm{~K}-\mathrm{W}$ non-parameter test of school-running level

\begin{tabular}{|c|c|c|c|c|c|c|c|}
\hline $\begin{array}{c}\text { School- } \\
\text { running level }\end{array}$ & $\begin{array}{l}\mathrm{Hu} \\
\text { man } \\
\text { cost }\end{array}$ & $\begin{array}{l}\text { Com } \\
\text { mon } \\
\text { cost }\end{array}$ & $\begin{array}{c}\text { Duty } \\
\text { cost }\end{array}$ & $\begin{array}{c}\text { Busine } \\
\text { ss cost }\end{array}$ & $\begin{array}{c}\text { Equi } \\
\text { pment } \\
\text { cost }\end{array}$ & $\begin{array}{c}\text { Repa } \\
\text { ir cost }\end{array}$ & $\begin{array}{c}\text { Othe } \\
\text { r cost }\end{array}$ \\
\hline Chi-Square & 5.42 & 5.42 & 39.9 & 117.59 & 14.44 & 20.55 & 21.04 \\
\hline df & 2 & 2 & 2 & 2 & 2 & 2 & 2 \\
\hline Asymp.Sig. & .067 & .067 & .000 & .000 & .001 & .000 & .000 \\
\hline
\end{tabular}

From the probability value of K-W statistics in the table, we can see that human cost and common cost (0.067) is greater than 0.05 , which means that under the significance level 0.05 , the input proportion of human cost and common cost of different levels of schools has no evident difference. But the probability values of other cost are less than the significance level 0.05 . So the proportion of other cost of different levels of schools has evident difference. Therefore, different school-running levels have great influence on cost proportions of secondary indexes. From the average rank statistics, we can see that the common proportion of colleges is the highest, that of undergraduates is secondary and that of emphases is the lowest. The business cost proportion of emphases is the highest, that of undergraduates is secondary and that of colleges is low. The equip ment cost proportion of colleges is the highest, that of undergraduates is secondary and that of emphases is the lowest. The repair cost proportion of undergraduates is high, that of colleges is secondary and that of emphases is low. The other cost proportions of emphases are the highest, that of undergraduates is secondary and that of colleges is low.

\section{Influence analysis of school-running category}

The school-running category of colleges and universities is divided into comprehensive colleges, science and engineering colleges, language teacher education colleges, agriculture and forestry colleges, medical colleges, art colleges, political-legal colleges and national colleges as control variables $(1,2,3,4,5,6,7,8$ and 9). The proportional cost of costs is input into the computer as observable variables ( 122 comprehensive colleges, 259 science and engineering colleges, 73 financial colleges, 217 language teacher education colleges, 46 forestry colleges, 94 medical colleges, 44 art colleges, 27 political-legal colleges and 14 national colleges). The analysis results are shown in Table 3.

Table 3 Mean order test of school-running category

\begin{tabular}{|c|c|c|c|c|c|c|c|}
\hline Code & $\begin{array}{c}\text { Huma } \\
\text { n cost }\end{array}$ & $\begin{array}{c}\text { Comm } \\
\text { on cost }\end{array}$ & $\begin{array}{c}\text { Duty } \\
\text { cost }\end{array}$ & $\begin{array}{c}\text { Busine } \\
\text { ss cost }\end{array}$ & $\begin{array}{c}\text { Equip } \\
\text { ment cost }\end{array}$ & $\begin{array}{c}\text { Repair } \\
\text { cost }\end{array}$ & $\begin{array}{c}\text { Other } \\
\text { cost }\end{array}$ \\
\hline 1 & 408.29 & 488.71 & 442.30 & 474.22 & 474.66 & 415.85 & 493.78 \\
\hline 2 & 458.67 & 438.33 & 443.16 & 489.81 & 436.22 & 415.66 & 440.60 \\
\hline 3 & 435.62 & 461.38 & 544.37 & 387.85 & 431.71 & 476.14 & 436.62 \\
\hline 4 & 473.45 & 423.55 & 413.82 & 368.88 & 495.18 & 436.48 & 455.44 \\
\hline 5 & 496.54 & 400.46 & 355.33 & 483.04 & 452.80 & 466.67 & 409.85 \\
\hline 6 & 455.18 & 441.82 & 431.96 & 541.18 & 438.73 & 500.18 & 395.06 \\
\hline 7 & 427.75 & 469.25 & 497.11 & 450.36 & 272.88 & 573.09 & 434.43 \\
\hline 8 & 273.63 & 623.37 & 626.59 & 431.44 & 443.11 & 560.11 & 509.26 \\
\hline 9 & 491.00 & 406.00 & 559.86 & 301.64 & 425.46 & 369.21 & 567.29 \\
\hline
\end{tabular}

Table $4 \mathrm{~K}-\mathrm{W}$ non-parameter test

\begin{tabular}{|c|c|c|c|c|c|c|c|}
\hline $\begin{array}{l}\text { School- } \\
\text { running } \\
\text { category }\end{array}$ & $\begin{array}{l}\text { Hum } \\
\text { an cost }\end{array}$ & $\begin{array}{c}\text { Com } \\
\text { mon cost }\end{array}$ & $\begin{array}{l}\text { Duty } \\
\text { cost }\end{array}$ & $\begin{array}{l}\text { Busin } \\
\text { ess cost }\end{array}$ & $\begin{array}{l}\text { Equip } \\
\text { ment } \\
\text { cost }\end{array}$ & $\begin{array}{l}\text { Repai } \\
\text { r cost }\end{array}$ & $\begin{array}{l}\text { Other } \\
\text { cost }\end{array}$ \\
\hline $\begin{array}{l}\text { Chi- } \\
\text { Square }\end{array}$ & $\begin{array}{lr} & 20.17 \\
8 & \end{array}$ & $\begin{array}{ll} & 20.17 \\
9 & \end{array}$ & $\begin{array}{ll} & 37.37 \\
2 & \end{array}$ & $\begin{array}{ll} & 49.85 \\
7 & \end{array}$ & $\begin{array}{lr} & 29.73 \\
1 & \end{array}$ & $\begin{array}{ll} & 27.92 \\
2 & \end{array}$ & $\begin{array}{ll} & 13.88 \\
7 & \end{array}$ \\
\hline $\mathrm{df}$ & 8 & 8 & 8 & 8 & 8 & 8 & 8 \\
\hline $\begin{array}{l}\text { Asymp.S } \\
\text { ig. }\end{array}$ & .010 & .010 & .000 & .000 & .000 & .000 & .085 \\
\hline
\end{tabular}

From the probability value of K-W statistics, we can see that cost proportion ( 0.085$)$ is less than significance level 0.05 except for other cost proportion ( 0.085$)$. So the secondary cost proportion of different categories of schools has evident difference except for other cost proportion. Different school-running categories have great influence on cost proportion of secondary indicators.

\section{Influence analysis of different administrative departments}

The administrative departments of different colleges are divided into central and local agencies as control variables ( 0 and 1). The cost proportional data is input into the computer as observable variables (100 central colleges and 796 local colleges). The analys is results are shown in Table 5 and Table 6. 
Table 5 Mean order test of administrative departments

\begin{tabular}{|c|c|c|c|c|c|c|c|}
\hline $\begin{array}{c}\text { C } \\
\text { ode }\end{array}$ & $\begin{array}{c}\text { Human } \\
\text { cost }\end{array}$ & $\begin{array}{c}\text { Comm } \\
\text { on cost }\end{array}$ & $\begin{array}{c}\text { Duty } \\
\text { cost }\end{array}$ & $\begin{array}{c}\text { Busine } \\
\text { ss cost }\end{array}$ & $\begin{array}{c}\text { Equip } \\
\text { ment cost }\end{array}$ & $\begin{array}{c}\text { Repair } \\
\text { cost }\end{array}$ & $\begin{array}{c}\text { Other } \\
\text { cost }\end{array}$ \\
\hline 0 & 456.5 & 440.4 & 452.6 & 426.0 & 465.3 & 459.9 & 433.7 \\
\hline 1 & 385.2 & 511.7 & 415.8 & 625.1 & 316.0 & 358.6 & 564.8 \\
\hline
\end{tabular}

Table $6 \mathrm{~K}-\mathrm{W}$ non-parameter test of adminis trative departments

\begin{tabular}{|c|c|c|c|c|c|c|c|}
\hline $\begin{array}{c}\text { Administra } \\
\text { tive } \\
\text { departments }\end{array}$ & $\begin{array}{c}\text { Huma } \\
\text { ncost }\end{array}$ & $\begin{array}{c}\text { Com } \\
\text { mon cost }\end{array}$ & $\begin{array}{c}\text { Duty } \\
\text { cost }\end{array}$ & $\begin{array}{c}\text { Busin } \\
\text { es cost }\end{array}$ & $\begin{array}{c}\text { Equip } \\
\text { ment cost }\end{array}$ & $\begin{array}{c}\text { Repai } \\
\text { r cost }\end{array}$ & $\begin{array}{c}\text { Other } \\
\text { cost }\end{array}$ \\
\hline Chi-Square & 6.793 & 6.793 & 1.809 & 53.00 & 29.79 & 13.72 & 22.99 \\
& 1 & 1 & 1 & 1 & 1 & 1 & 1 \\
\hline df & .009 & .009 & .179 & .000 & .000 & .000 & .000 \\
\hline Asymp.Sig. & & & & 5 & & \\
\hline
\end{tabular}

From the probability value of K-W statistics in the above table, we can see that the cost proportion is less than significance level 0.05 , so there is evident difference for various secondary cost proportions in different categories of colleges. Different administrative departments have great influence on cost proportion of secondary indicators. From the mean rank statistics, we can get that the human cost proportion of local colleges is higher than that of central colleges, the public cost of local colleges is lower than that of central colleges, the duty cost proportion of local colleges is higher than that of central colleges, the business cost proportion of central colleges is higher than that of local colleges, the equipment cost proportion of local colleges is higher than that of central colleges, repair cost proportion of local colleges is higher than that of central colleges, and other cost proportion of central colleges is lower than that of local colleges.

\section{III.INPUT-OUTPUT ANALYSIS OF COLLEGES AND UNIVERSITIES}

From the analys is results of cost proportions, we can get if the input is seen as resource input, the location of resources in colleges is not balanced. The paper uses relevant data for regression analysis, as follows.

The number of students is dependent variable, and various cost input is independent variable. The regression analysis of dependent variable for independent variable is made. IN the process of regression analysis, school-running level and membership of schools are selected as control variables. From the scatter diagram of dependent variables and independent variables, we can see that there is linear relationship. In order to compute the changing elasticity of dependent variables for various resources, the double logarithmic model is selected, and all indexes are selected for the equation. And the results are not ideal. There may be multiple characteristic phenomena between first-level indicators, secondary indicators, teacher resources, material resources, school-running level and school-running category. The regression model is shown in the following formula.
Total cost input model,

$$
\ln y=\mathrm{B}_{0}+\mathrm{B} \ln _{\mathrm{x}}+\mathrm{B}_{8} \mathrm{x}_{8}+\mathrm{B}_{9} \mathrm{x}_{9}+\mathrm{B}_{10} \mathrm{x}_{10}+\mathrm{B}_{11} \mathrm{x}_{11}
$$

(1)

First-level index input model,

$$
\ln \mathrm{y}=\mathrm{B}_{0}+\mathrm{B}_{1} \ln \mathrm{x}_{1}+\mathrm{B}_{2} \ln \mathrm{x}_{2}+\mathrm{B}_{8} \mathrm{x}_{8}+\mathrm{B}_{9} \mathrm{x}_{9}+\mathrm{B}_{10} \mathrm{x}_{10}+\mathrm{B}_{11} \mathrm{x}_{11}
$$

(2)

Secondary indicator input model,

$\ln y=B_{0}+B_{3} \ln x_{3}+B_{4} \ln x_{4}+B_{5} \ln x_{5}+B_{6} \ln x_{6}+B_{7} \ln x_{7}+B_{8} x_{8}+B_{9} x_{9}+B_{10} x_{10}+B_{11} x_{11}$ (3)

In the formula,

$y$ - the number of students,

$\mathrm{x}$ - total cost input

$\mathrm{x}_{1}, \mathrm{x}_{2}, \mathrm{x}_{3}, \mathrm{x}_{4}, \mathrm{x}_{5}, \mathrm{x}_{6}$ and $\mathrm{x}_{7}$ means the input of human cost, duty cost, common cost, business cost, equipment cost, repair cost and other cost

$\mathrm{x}_{8} 、 \mathrm{x}_{9}-$ school-running level, $\mathrm{x}_{8}=0$ means nonemphasis college, $\mathrm{x}_{8}=1$ means emphasis college, $\mathrm{x}_{9}=0$ means college, $x_{9}=1$ means undergraduate;

$\mathrm{x}_{10}$ - administrative department, $\mathrm{x}_{10}=0$ means local college, and $x_{10}=1$ means central college.

$\mathrm{x}_{11}$ - the location. $\mathrm{x}_{11}=0$ means economic development level is not high, and $\mathrm{x}_{11}=1$ means economic development is good.

From model (1), we can see that the coefficient of total input is evidently less than 1 . If the theory is consistent with the practice, the colleges in our country are in the process of scale benefit reducing. In fact, there are 5,289 students in colleges in 2000, which has great difference from $8000-$ 10000 in theory. There are two possibilities, as follows. The first possibility is that the educational input of colleges has exceeded the requirements of society on higher education, which makes return reduce. However, in fact, the requirements of society on higher education increases, which is impossible. The second possibility is that the cost structure of colleges in our country is not rational, which makes benefit reduce. And the practice supports the conclusion.

From the analysis results of model (2) and (3), we can see that the change of the number of students is influenced by human capital and duty cost. It indicates that for educational decision-makers, the functions of cost input are not the same. Some cost inputs are hard and need to be 
ensured, and they can' $t$ be changed randomly. But some resources are soft, and allow elasticity and flexibility.

\section{IV.EVALUATION ON EDUCATIONAL COST STRUCTURE IN COLLEGES AND UNIVERSITIES}

\section{A. Fuzzy comprehensive evaluation system of expense benefit in colleges and universities}

a.Establishing factors. The resource evaluation indicators influencing cost input utilization of higher education are used as the set of factors evaluating objects, which is called factor set. It is a common set, and is represented by $\mathrm{A}$,

$$
A=\left\{a_{1}, a_{2}, \cdots, a_{n}\right\},
$$

In the formula, $\mathrm{n}$ is the total number of factors, and the factors have different degrees of fuzziness.

b. Establishing weight set. In order to reflect the importance of factors, each factor a should be assigned certain weight to establish weight set $\mathrm{U}$ corresponding to the set A.

$$
\mathrm{U}=\left\{\mathrm{u}_{1}, \mathrm{u}_{2}, \cdots, \mathrm{u}_{\mathrm{n}}\right\}, \quad \sum_{i=1}^{n} U i=1
$$

c. Establishing evaluation set. $\sum_{i=1} \quad$ Evaluation set is the set consisting of evaluation results which are made by evaluation objects, and it is represented by $\mathrm{B}$.

$$
B=\left\{b_{1}, b_{2}, \cdots, b_{m}\right\} \text {, }
$$

In the formula, $\mathrm{m}$ is the total number of evaluation results. The objective of fuzzy expense efficiency evaluation is to select the best evaluation result based on influencing factors.

d. Single-factor fuzzy evaluation. A single factor is evaluated to determine the membership degree of evaluation objects to evaluation set $\mathrm{B}$, which is called single-factor fuzzy evaluation. The I factor a in factor set A is selected for evaluation, and the membership of it to the $j$ factor $b_{j}$ in factor set $B$ is $r_{i j}$, single-factor evaluation on $a_{i}$ can get fuzzy set,

$$
\mathrm{R}_{\mathrm{i}}=\left\{\mathrm{r}_{\mathrm{i} 1}, \mathrm{r}_{\mathrm{i} 2}, \cdots, \mathrm{r}_{\mathrm{im}}\right\}
$$

After evaluating all single factors $\mathrm{a}_{\mathrm{i}}$, we can get

$$
R=\left[\begin{array}{c}
R_{1} \\
R_{2} \\
\vdots \\
R_{n}
\end{array}\right]=\left[\begin{array}{cccc}
r_{11} & r_{12} & \cdots & r_{1 m} \\
r_{21} & r_{22} & \cdots & r_{2 m} \\
\vdots & \vdots & \vdots & \vdots \\
r_{n 1} & r_{n 2} & \cdots & r_{n m}
\end{array}\right] \begin{aligned}
& \left(0 \leqslant \mathrm{r}_{\mathrm{ij}} \leqslant\right. \\
& 1, \mathrm{i}=1,2, \cdots \\
& \mathrm{j}=1,2, \cdots \mathrm{m})
\end{aligned}
$$

e. Fuzzy comprehensive evaluation. Single-factor fuzzy evaluation reflects the influence of a factor on evaluation objects. The mathematical model of fuzzy comprehensive evaluation is $\mathrm{V}=\mathrm{U} \bigcirc \mathrm{R}$. The number $\mathrm{V}$ can select the minimum to get $n$ numbers. Then, the maximum of $n$ numbers is selected as the $\mathrm{j}$ number of $\mathrm{V}$. Lastly, $\mathrm{v}$ is normalized to get the mathematical basis $\mathrm{V}^{\prime}$ of final evaluation.

\section{B. Educational cost-benefit fuzzy comprehensive evaluation example}

a. Selecting factors which can reflect cost service efficiency of higher education, $\mathrm{a}_{1}$ (proportion of teachers to students), $a_{2}$ (growth rate of teaching expense), $a_{3}$ (experimental expenditure rate), a4 (supply0demand proportion of graduates), $a_{5}$ (quality course rate) and $a_{6}$ (award rate of paper).

$$
A=\left\{a_{1}, a_{2}, a_{3}, a_{4}, a_{5}, a_{6}\right\}
$$

b. According to evaluation standard of national College Board for teaching and management of industrial colleges in 1997 , we can see that the weight coefficients of the above factors are $30 \%, 20 \%, 10 \%, 20 \%, 15 \%$ and $5 \%$. And the weight set $\mathrm{U}$ corres ponding to the set $\mathrm{A}$ is

$$
\mathrm{U}=\left\{\begin{array}{llll}
0.3, & 0.2, & 0.1, & 0.2,0.15,0.5
\end{array}\right. \text {. }
$$

c. When cost-benefit of higher education receives fuzzy comprehensive evaluation, the established evaluation set is

$\mathrm{B}=\{$ excellent, good, common, worse, bad $\}$.

$\mathrm{d}$. If investigation, questionnaire and management are implemented, the evaluators can determine the membership according to the mastery degree. The configuration ratio of teachers and students in a college is that $15 \%$ of people considers excellent, $30 \%$ of people considers good, $25 \%$ of people considers general, $20 \%$ of people considers worse and $10 \%$ of people considers bad. The evaluation of evaluators on the proportion of teachers to students can get $\mathrm{R}_{1}=$

\begin{tabular}{|c|c|c|c|c|c|}
\hline & {$[0.15$} & 0.3 & 0.25 & 0.20 & 0.10 \\
\hline & 0.35 & 0.30 & 0.15 & 0.10 & 0.10 \\
\hline & 0.15 & 0.20 & 0.40 & 0.20 & 0.05 \\
\hline & 0.10 & 0.15 & 0.40 & 0.25 & 0.10 \\
\hline $\begin{array}{l}\text { cording to the } \\
\text { zy mathematical }\end{array}$ & 0.15 & 0.30 & 0.40 & 0.10 & 0.05 \\
\hline ( can & 0.10 & 0.25 & 0.30 & 0.25 & 0.10 \\
\hline
\end{tabular}
$\{0.15,0.3,0.25,0.2,0.1\}$.

The evaluation on teaching expense growth rate, experimental expenditure rate, employment supply-demand ratio of graduates, quality course rate and award rate of paper is as follows.

$$
\begin{aligned}
& R_{2}=\left\{\begin{array}{lllll}
0.35, & 0.3, & 0.15, & 0.1, & 0.1
\end{array}\right\} ; \\
& \mathrm{R}_{3}=\left\{\begin{array}{lllll}
0.15, & 0.2, & 0.4, & 0.2, & 0.05
\end{array}\right. \text {; } \\
& R_{4}=\left\{\begin{array}{lllll}
0.1, & 0.15, & 0.4, & 0.25, & 0.1
\end{array}\right\} \text {; } \\
& R_{5}=\left\{\begin{array}{lllll}
0.15, & 0.3, & 0.4, & 0.1, & 0.05
\end{array} ;\right. \\
& R_{6}=\left\{\begin{array}{lllll}
0.1, & 0.25, & 0.3, & 0.25, & 0.1
\end{array}\right\} \text {. }
\end{aligned}
$$

And we can get a fuzzy relationship matrix $\mathrm{R}$, as follows. that the mathe matical model reflecting the educational cost-benefit in the college is

$$
\begin{gathered}
\mathrm{V}=\mathrm{U} \bigcirc \mathrm{R}= \\
{[0.20,0.30,0.25,0.20,0.10] 。}
\end{gathered}
$$

After normalization, we can get: $0.20+0.30+0.25+$ $0.20+0.10=1.05$, which means that $\mathrm{V}^{\prime}$ is :

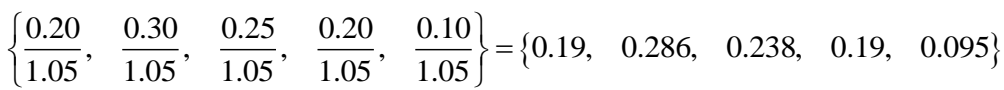


The evaluation results indicate that there is $19 \%$ of excellent educational cost-benefit in colleges, there is $28.6 \%$ of good, there is $23.8 \%$ of common, there is $19 \%$ of worse and $9.5 \%$ of bad educational cost-benefit. According to the maximal me mbership princip le of fuzzy mathematics, $28.6 \%$ $>23.8 \%>19 \%>9.5 \%$, so we can get that the educational cost-benefit of the college is good, and the educational cost structure is rational.

\section{V.CONCLUSIONS}

Applying the evaluation index system to evaluate resource utilization efficiency is good for macro management of educational admin istrative departments. By evaluation, the administrative departments can know the problems of educational cost structure, which provides bas is for correct investment decision. Generally speaking, the funds should be invested in schools with high resource utilization efficiency. And colleges with low resource utilization efficiency should focus on the tapping job. And it is good for management of colleges to improve efficiency. Through overall evaluation on resource utilization efficiency, the colleges can know the position or rank, which provides reference for the job in the future. And we can evaluate single factor to reflect resource utilization efficiency.

\section{REFERENCES}

[1] Chong M. Lau, Mahfud Sholihin. Financial and Non. financial Performance Measures . How do They Affect Job Satisfaction[J]. The British Accounting Review . 2005 , 12(37). 389-413

[2] Ken S. Cavalluzzo, Christopher D . Ittner . Implementing Performance Measurement Innovation . Evidence from Government[J]. Accounting, Organizations and Society. 2004, $3(29) .243-267$

[3] Zahirul Hoque . Linking Environmental Uncertainty to Non. financial Performance Measures and Performance : a Research Note[J]. TheBritish Accounting Review. 2005， 12(37). 471-481

[4] Mary A. Malina, Frank H. Selto. Choice and Change of Measures in Performance Measurement Models [J]. Management Accounting Research. 2004, 12(15) .441-469

[5] Abdel-Maksoud, David Dugdale, Robert Luther. Non. financial performance measurement

[6] in manufacturing companies[J] . The British Accounting Review. 2005, 9(37). 261-297

[7] Carter N. Greer P.1993,Evaluating agencies next step s and performance indicators. Public administration, 71:407-416.

[8] Guthrie J.E.and Parker L.D,1999,A Quarter of a Century of Performance Auditing in the Australian Federal Public Sector:A Malleable Masque(3):302-332.

[9] Cave,Martin,Hanny,Stephen and Kogan,Mauric,"The Use of Performance Indicators in Higher Education: A Critical Analysis of Developing Practice",Jessica Kingsleg Publishers Ltd. , 1988.P17,P20,P19-20,P106-107,P118-P39.

[10] Jaap Schenrens, CeesGlas, Sally H. Thoms : Educational Evaluation, Assessment, AtldMonitoring, A systemicApproach, Swcb\&Zeitlinger Publishers. 2003, P304

[11] Quinn E. R, Faerman R. S, Thompson P. M, McGrath R . M . . Becominga Master Manager : ACompany Framework. NewYork John W. 1ey\&Son, 1985. 